\title{
Characteristics and genesis of Inceptisols with placic horizons in the subalpine forest soils of Taiwan
}

\author{
Sen-Po Wu, Zueng-Sang Chen* \\ Graduate Institute of Agricultural Chemistry, National Taiwan University, 1, Sec. 4, Roosevelt Road, Taipei 106-17, Taiwan
}

Received 19 September 2003; received in revised form 13 July 2004; accepted 3 September 2004

Available online 27 October 2004

\begin{abstract}
Three pedons of Inceptisols with placic horizons were selected to study the characteristics and genesis of subalpine forest soils located in Shang-Hsing Mountain in Ilan county, northeastern Taiwan. The selected pedons were elevated from 1900 to $2100 \mathrm{~m}$ and derived from slate formed in the late Quaternary age. The vegetation types are dominated by red cypress (Chamaecyparis formosensis Matsum) and Taiwan Chinese fir (Taiwania cryptomerioides Hay). The annual rainfall is about $3000 \mathrm{~mm}$ and mostly falls from April to October. The soil moisture regime is perudic, and the soil temperature regime is mesic. Three Inceptisols can be classified as Lithic Dystrudept and Oxyaquic Dystrudept based on USDA Soil Taxonomy or Cambisol based on World reference base system. Clear illuvial pedogenic processes were observed by the bleached albic (E) horizon and the underlain placic (Bs) horizons, which were characterized on the changes of soil morphology, micromorphology, soil texture and chemical compositions. The placic horizon appeared to be dominated by amorphous iron and free iron oxides, with lesser amounts of amorphous aluminum and free aluminum oxides. The genesis of the placic horizons in the study area was proposed as two stages. In the first stage, the perched water was located between albic horizon and cambic horizon after a storm owing to the texture changes of these two horizons. In the second stage, Fe of the upper part of the pedon was reduced, then be mobilized and reoxidized it in the boundary of $\mathrm{E}$ and $\mathrm{Bw}$ horizon. Therefore, the boundary of placic horizon has a wavy or irregular boundary. In addition, the genesis of placic horizon may also relate to the precipitation of mobile $\mathrm{Fe}$ at higher soil $\mathrm{pH}$ value and oxidizing soil contacts below the mineral soil surface. Although we do not find the argillic horizon formed below the placic horizon, Ultisols are a major soil order formed in the level landscape position of the study area.
\end{abstract}

(C) 2004 Elsevier B.V. All rights reserved.

Keywords: Inceptisols; Placic horizon; Genesis; Subalpine forest soils; Cambisols

\section{Introduction}

* Corresponding author. Tel.: +88622369 8349; fax: +886223924335 .

E-mail address: soilchen@ccms.ntu.edu.tw (Z.-S. Chen).
The placic horizon has been defined as a thin, black to dark reddish pan that is cemented by iron (or iron and manganese) and organic matter. It has a

0016-7061/\$ - see front matter (C) 2004 Elsevier B.V. All rights reserved. doi:10.1016/j.geoderma.2004.09.007 
minimum thickness of $1 \mathrm{~mm}$ and, where associated with spodic materials, is less than $25-\mathrm{mm}$ thick (Soil Survey Staff, 1999). A placic horizon is relatively impermeable to water and plant roots. It occurs in the sola of some Spodosols as a thin wavy or convoluted horizon that transgresses several subhorizons (McKeague et al., 1967). In some regions, it occurs within or immediately below the albic E horizon (Soil Survey Staff, 1975). Placic horizons are usually associated with perudic to aquic soil moisture regimes in coastal regions (McKeague et al., 1983).

Soils with a placic horizon are classified as Spodosols or Inceptisols. The placic horizon, however, is also found in Histosols (McKeague et al., 1968; Clayden et al., 1990). The genesis of placic horizon is still not completely understood. Several hypotheses have been proposed to explain this genesis (Crompton, 1952; Conry et al., 1996; Chen et al., 1989, 1995; Clayden et al., 1990; Hseu et al., 1999; Lapen and Wang, 1999). Placic horizons are formed in a wide range of landscapes from temperate to tropical zone but are always associated with the climate condition under udic or perudic soil moisture regimes.

Taiwan is located at the tropical and subtropical climatic zones. The subalpine forest regions are suitable for the formation of Podzolic soils, including Ultisols, Inceptisols, Entisols and Spodosols (Chen and Tsai, 2000). The Podzolic soils were formed at the elevation that is higher than $1900 \mathrm{~m}$, cool and humid climate, high precipitation (>3000 $\mathrm{mm} /$ year) mostly from April to October and dominant with the coniferous vegetation type in Taiwan (Chen et al., 1989, 1995; Liu et al., 1994; Li et al., 1998; Hseu et al. 1999). However, in addition to sandstone, parent materials of subalpine forest areas of Taiwan also include shale or slate, which are easily weathered to a finer texture soil. In this condition, the water slowly flows into the soil and provides the cycling of reduced and oxidized (or wet and dried) conditions. The cycling of reduced and oxidized conditions is one of the important factors for the genesis of placic horizon in Taiwan (Chen et al., 1989, 1995; Clayden et al., 1990; Hseu et al., 1999).

The objectives of this study are (i) to study the soil characteristics and soil classification of three Inceptisols with placic horizons, (ii) to investigate the micromorphology of placic horizon and (iii) to propose the genesis of placic horizon of these pedons.

\section{Materials and methods}

\subsection{Soil and environmental conditions}

Three Inceptisols with placic horizons were selected in the Shang-Hsing Mountain area (around $24^{\circ} 32^{\prime} \mathrm{N}, 121^{\circ} 56^{\prime}$ E) of Ilan county, northeastern Taiwan (Fig. 1). The slope of selected subalpine forest soils ranged from $20 \%$ to $60 \%$, and the elevation of three soils ranged from 1900 to $2100 \mathrm{~m}$ above sea level (asl). The parent material of study area consists of slate formed in the late Quaternary. The vegetation types are dominated by red cypress (Chamaecyparis formosensis Matsum) and Taiwan Chinese fir (Taiwania cryptomerioides Hay). Some environmental characteristics of the soil pedons are listed in Table 1. The mean annual air temperature is $10.7^{\circ} \mathrm{C}$, and the mean annual precipitation is $3000 \mathrm{~mm}$. The rainfall mostly occurs from April to October.

\subsection{Laboratory analysis}

Soil samples were collected from each horizon of three soil pedons for physical and chemical analyses. Soil samples were air dried and slightly ground to

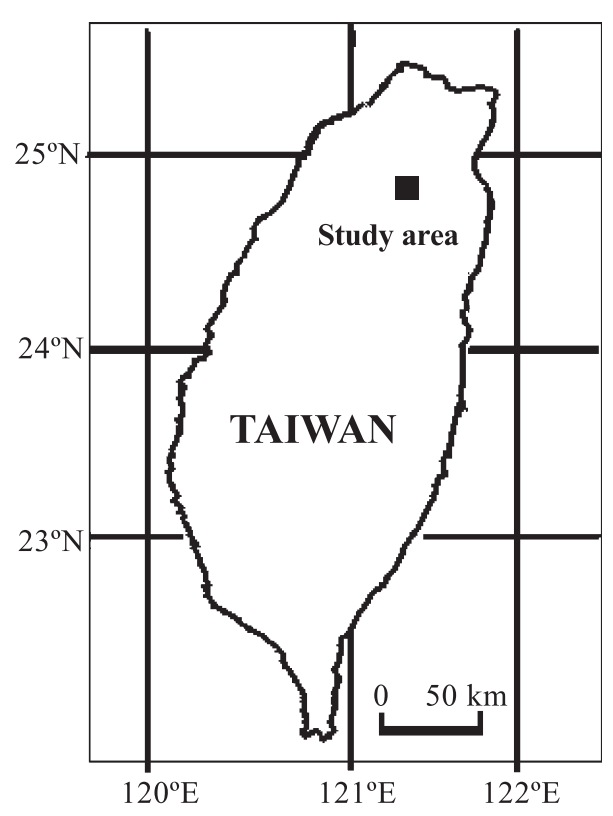

Fig. 1. The location of pedons studied in Taiwan. 
Table 1

The environment condition of three pedons in the study area

\begin{tabular}{|c|c|c|c|c|c|c|c|}
\hline \multirow[t]{2}{*}{ Location } & \multirow[t]{2}{*}{ Physiographic position } & \multirow{2}{*}{$\frac{\text { Elevation }}{\text { meter }}$} & \multirow{2}{*}{$\begin{array}{l}\text { Slope } \\
\text { degree }\end{array}$} & \multirow[t]{2}{*}{ Facing direction } & \multirow[t]{2}{*}{$\mathrm{SMR}^{\mathrm{a}}$} & \multirow[t]{2}{*}{$\mathrm{STR}^{\mathrm{a}}$} & \multirow[t]{2}{*}{ Parent materials } \\
\hline & & & & & & & \\
\hline \multicolumn{8}{|c|}{ Pedon SH1: fine, mixed, mesic, Lithic Dystrudept } \\
\hline $\begin{array}{lll}24^{\circ} 32^{\prime} & 49^{\prime \prime} \mathrm{N} \\
121^{\circ} & 35^{\prime} \quad 18^{\prime \prime} \mathrm{E}\end{array}$ & Summit & 2000 & $<5$ & 210 & Udic & Mesic & Slate \\
\hline \multicolumn{8}{|c|}{ Pedon SH2: fine, mixed, mesic, Lithic Dystrudept } \\
\hline $\begin{array}{l}24^{\circ} 29^{\prime} \quad 45^{\prime \prime} \mathrm{N} \\
121^{\circ} 31^{\prime} \quad 40^{\prime \prime} \mathrm{E}\end{array}$ & Summit & 1920 & $<5$ & 180 & Udic & Mesic & Slate \\
\hline \multicolumn{8}{|c|}{ Pedon SH3: fine, mixed, mesic, Oxyaquic Dystrudept } \\
\hline $\begin{array}{l}24^{\circ} 31^{\prime} \quad 51^{\prime \prime} \mathrm{N} \\
121^{\circ} 37^{\prime} \quad 01^{\prime \prime} \mathrm{E}\end{array}$ & Shoulder & 1940 & 21 & 115 & Perudic & Mesic & Slate \\
\hline
\end{tabular}

${ }^{\text {a }} \mathrm{SMR}$ —-soil moisture regime, STR—soil temperature regime.

pass a 2-mm sieve. Bulk density was measured by paraffin method (Blake and Hartge, 1986). Particlesize distribution was determined by pipette method (Gee and Bauder, 1986). Soil pH was determined with a soil/water ratio of $1: 1$ and soil/1 $\mathrm{M} \mathrm{KCl}$ ratio of 1:2.5 (McLean, 1982). Organic C was determined by the Walkley-Black wet combustion method (Nelson and Sommers, 1982). Cation exchange capacity (CEC) and exchangeable bases were measured using ammonium acetate extraction (Thomas, 1982). Different forms of $\mathrm{Fe}$ and $\mathrm{Al}$ were extracted by dithionitecitrate-bicarbonate (DCB, $\mathrm{Fe}_{\mathrm{d}}$ and $\mathrm{Al}_{\mathrm{d}}$; Mehra and Jackson, 1960), ammonium oxalate ( $\mathrm{pH} 3.0, \mathrm{Fe}_{\mathrm{o}}$ and $\mathrm{Al}_{\mathrm{o}}$; McKeague and Day, 1966) and sodium pyrophosphate $\left(\mathrm{pH} 10.0, \mathrm{Fe}_{\mathrm{p}}\right.$ and $\mathrm{Al}_{\mathrm{p}}$; Loveland and Digby, 1984). Optical density of the oxalate extract (ODOE) of soils was also determined by ammonium oxalate (Daly, 1982).

\subsection{Thin section analysis}

For soil micromorphological studies, Kubiena boxes were used to collect undisturbed soil blocks in the field. After air drying, vertically oriented thin sections $(5 \times 7 \mathrm{~cm})$ with thickness of $30 \mu \mathrm{m}$ were prepared by Spectrum Petrographics (Oregon, USA). Thin sections were examined under a polarized microscope (AFX-II Type, Nikon), and the micromorphology was described according to the terminology of Bullock et al. (1985).

\section{Results and discussion}

\subsection{Soil morphology}

Soil morphological characteristics of the three pedons are listed in Table 2. All pedons have soil properties associated with Podzols and suggest strong eluviation and illuviation of soluble salts, $\mathrm{Fe}, \mathrm{Mn}$, and other materials. All pedons have a dark organic and mineral (O/A) surface, a gray albic (E) horizon, a dark red placic (Bs) horizon and a brownish yellow $\mathrm{B}$ horizon. The color of the albic E horizon is gray (10YR 6/1, 7.5YR 6/1 or 10YR 7/1). All albic E horizons have a massive structure that is enhanced by wet soil conditions and was identified as a redoximorphic feature. Gleyzation of the albic material was apparently affected by the poor drainage resulting from the underlying placic horizon (Hseu et al., 1999).

The thickness of the placic horizons ranged from 2 to $5 \mathrm{~mm}$ (Fig. 2). The placic horizon had colors of 2.5YR 4/6 in pedon SH1, 2.5YR 5/8 in pedon SH2 and 2.5YR 4/8 and 2.5YR 2.5/1 in pedon SH3 (Table $2)$. Two distinct phases were found in these placic horizons. A dark hard iron pan occurred in the upper part of the Bs horizon of pedon SH1 accompanied by a less-dense plasma immediately below the main pan (Fig. 2a). In the placic horizon of pedons $\mathrm{SH} 2$ and SH3, darker red iron bands and lighter dense plasma paralleled each other (Fig. 2b and c).

The thickness of placic horizon is about $5 \mathrm{~mm}$ and has an abrupt and wavy boundary (Fig. 2). The placic 
Table 2

The morphological characteristics of three pedons

\begin{tabular}{|c|c|c|c|c|c|c|c|}
\hline Horizon & Depth $(\mathrm{cm})$ & Munsell color & Texture $^{\mathrm{a}}$ & Structure $^{\mathrm{b}}$ & Consistence $^{\mathrm{c}}$ & Rootsd & Boundary \\
\hline \multicolumn{8}{|c|}{ SH1, elevation $2000 \mathrm{~m}$} \\
\hline $\mathrm{O} / \mathrm{A}$ & $0-3$ & 10YR 3/1 & $\mathrm{L}$ & $1 \mathrm{vf}$ and fgr & fri & $\mathrm{mm}$ and $\mathrm{c}$ & gs \\
\hline $\mathrm{E}$ & $3-12$ & $\begin{array}{l}\text { 10YR 6/1 } \\
7.5 \text { YR } 5 / 8(\operatorname{mot})^{\mathrm{f}}\end{array}$ & $\mathrm{SiL}$ & massive & $\mathrm{fm}, \mathrm{ss}$ and $\mathrm{sp}$ & $\mathrm{cf}$ and $\mathrm{m}$ & aw \\
\hline Bs & $12-12.5$ & $2.5 \mathrm{YR} 4 / 6$ & - & - & $\mathrm{h}$ & - & aw \\
\hline $\mathrm{Bw}$ & $12.5-40$ & 10YR 6/8 & $\mathrm{SiCL}$ & $2 \mathrm{~m}$ and cabk & $\mathrm{fm}, \mathrm{ss}$ and $\mathrm{sp}$ & $\mathrm{ff}$ and $\mathrm{m}$ & $\mathrm{d}$ \\
\hline $\mathrm{C}$ & $>40$ & $2.5 \mathrm{Y} 6 / 6$ & SL & $2 \mathrm{fsbk}$ & $\mathrm{fm}$ & fvf & - \\
\hline \multicolumn{8}{|c|}{ SH2, elevation $1920 \mathrm{~m}$} \\
\hline $\mathrm{O} / \mathrm{A}$ & 3-0 & 7.5YR 2.5/1 & $\mathrm{L}$ & mucky & - & - & - \\
\hline $\mathrm{AE} 1$ & $0-18$ & 10YR 5/1 & SiL & massive & $\mathrm{sfm}, \mathrm{ss}$ and $\mathrm{sp}$ & sm and $\mathrm{c}$ & gs \\
\hline AE2 & $18-27$ & 10YR 5/1 & $\mathrm{SiL}$ & massive & $\mathrm{fm}, \mathrm{ss}$ and $\mathrm{sp}$ & svf and $\mathrm{f}$ & ds \\
\hline $\mathrm{E}$ & $27-36$ & 7.5 YR $6 / 1$ & $\mathrm{SiCL}$ & massive & $\mathrm{fm}, \mathrm{s}$ and $\mathrm{p}$ & sm and c & aw \\
\hline Bs & $36-36.5$ & $2.5 \mathrm{YR} 5 / 8$ & - & - & $\mathrm{h}$ & - & aw \\
\hline $\mathrm{Bw}$ & $36.5-56$ & 10YR 6/8 & $\mathrm{SiCL}$ & $2 \mathrm{vf}$ and fabk & $\mathrm{sfm}, \mathrm{s}$ and $\mathrm{p}$ & - & $\mathrm{d}$ \\
\hline $\mathrm{C}$ & $>56$ & $2.5 \mathrm{Y} 6 / 6$ & SL & $2 \mathrm{fsbk}$ & - & fvf & - \\
\hline \multicolumn{8}{|c|}{ SH3, elevation $1940 \mathrm{~m}$} \\
\hline $\mathrm{O}$ & $5-0$ & $7.5 \mathrm{YR} 3 / 2$ & - & mucky & - & - & cs \\
\hline A & $0-10$ & 5 YR $2.5 / 2$ & $\mathrm{~L}$ & $2 v f$ and fgr & - & mvf, sm & aw \\
\hline E1 & $10-15$ & $10 \mathrm{YR} 4 / 2$ & $\mathrm{~L}$ & massive & $\mathrm{fm}, \mathrm{ss}$ and $\mathrm{sp}$ & fvf and $\mathrm{f}$ & aw \\
\hline E2 & $15-25$ & 10YR $7 / 1$ & CL & massive & $\mathrm{s}$ and $\mathrm{p}$ & fvf and $\mathrm{f}$ & aw \\
\hline Bs & $25-25.3$ & $\begin{array}{l}2.5 \text { YR } 4 / 8(70 \%) \\
2.5 \text { YR } 2.5 / 1(30 \%)\end{array}$ & - & - & $\mathrm{h}$ & - & aw \\
\hline Bw1 & $25.3-55$ & $10 \mathrm{YR} 6 / 8$ & $\mathrm{SiCL}$ & $2 v f$ and fabk & $\mathrm{fm}, \mathrm{ss}$ and $\mathrm{sp}$ & fvf and $\mathrm{f}$ & d \\
\hline $\mathrm{Bw} 2$ & $55-75$ & 10YR 6/8 & $\mathrm{SiCL}$ & $2 v f$ and fabk & $\mathrm{fm}$, ss and $\mathrm{sp}$ & fvf and $\mathrm{f}$ & d \\
\hline $\mathrm{BC}$ & 75-100 & 10YR 6/8 & $\mathrm{SiCL}$ & $2 \mathrm{vf}$ and fabk & $\mathrm{fm}$, ss and sp & fvf and $\mathrm{f}$ & $\mathrm{d}$ \\
\hline C & $>100$ & $2.5 \mathrm{Y} 6 / 6$ & $\mathrm{SL}$ & $2 \mathrm{fsbk}$ & - & fvf & - \\
\hline
\end{tabular}

${ }^{a} \mathrm{SiCL}$ — silty clay loam, SiL—silt loam, CL—clay loam, SL—sandy loam, L-loam.

b 1 - weak, 2-moderate, vf-very fine, f-fine, m-medium, gr — vgranular, abk — angular blocky, sbk-subangular blocky.

${ }^{\mathrm{c}} \mathrm{fm}$ - firm, fri-friable, s - sticky, p - plastic, ss — slightly sticky, sp — slightly plastic, vs — very sticky, vp — vvery plastic, h-hard.

d $\mathrm{c}$-common, $\mathrm{m}$ - many, s-some, f-few, c-coarse, $\mathrm{m}$ - medium, $\mathrm{f}$ - fine, vf-very fine.

e a-abrupt, c-clear, s-smooth, g-gradual, d-diffuse, w-wavy, i-irregular, b-broken.

${ }^{\mathrm{f}}$ mottle color.

horizon is too dense to be penetrated by roots. The soil between $\mathrm{E}$ horizon and $\mathrm{Bw}$ horizon have an abrupt texture change. This change of clay content may affect vertical water movement and relate to the formation of the placic horizons of three pedons.

\subsection{Soil micromorphology}

In the boundary area between albic (E) and placic (Bs) horizon, the soils showed an abrupt change in micromorphological characteristics (Fig. 2). The lower part of $\mathrm{E}$ horizon have a large amount of crystalline quartz materials, but the upper part of Bs horizon have cracked, parallel and isotropic iron and manganese matrices (Fig. 3a). The general micro- morphological characteristics of the placic horizons for the three pedons are similar. Brewer (1964) reported that iron pans originally have a granular fabric that has been modified by various degrees of cementation. They indicated grain coatings that could be found in the placic horizon. In contrast, all the fabrics in the placic horizons in the present study are isotropic.

Some different micromorphological characteristics were found between the upper part and lower part of placic (Bs) horizon (Fig. 3b). The upper part of placic horizon showed a dark red isotropic Fe oxide material (Fig. $3 b$ and c), and the lower part of the placic horizon showed a black to a reddish dense plasma with soil matrixes (Fig. $3 b$ and d). The fabric of the 

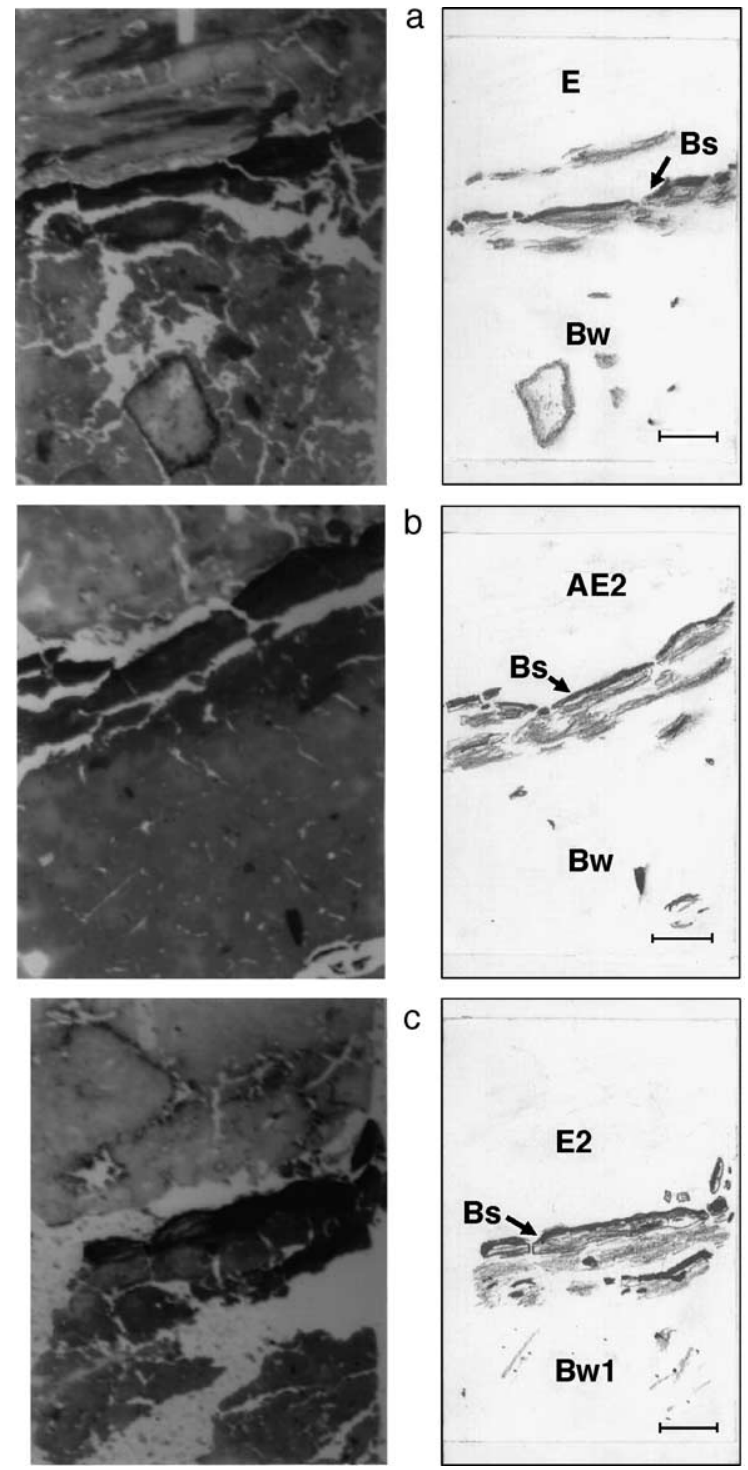

Fig. 2. Morphological characteristics of placic horizon of (a) SH1, (b) $\mathrm{SH} 2$ and (c) $\mathrm{SH}$. These photos were copied from the glass specimen of thin section. Scale of bar is $1 \mathrm{~cm}$.

placic horizons mainly consisted of dense plasma and was cemented by oxidized $\mathrm{Fe}$ and $\mathrm{Mn}$ materials. Intergranular voids (v) were found in the hard portion of the placic horizon in the three pedons (Fig. 3b and c).

The micromorphology of the placic horizons indicated higher bulk density and a maximum accumulation of $\mathrm{Fe}$ oxides (Tables 3 and 4). This character indicated that the soluble $\mathrm{Fe}$ and $\mathrm{Mn}$ was leached from $\mathrm{O} / \mathrm{A}$ and $\mathrm{E}$ horizons and then accumulated in the upper part of the placic horizon.

We did not find significant evidence of oriented illuvial clay in the cambic horizons $(\mathrm{Bw})$. This indicates that clay illuviation did not occur in the cambic horizon after the formation of placic horizon. Owing that the illuviation of clay is not sufficient to promote the formation of an argillic horizon, we propose that the clay content of cambic $(\mathrm{Bw})$ horizon was derived from its parent material. This situation is also consistent with the formation of placic horizons. After our survey in the study area, we found that some forest soils can be classified as Typic Hapludults based on Soil Taxonomy if the soils have illuvial clays, especially on the level topographic surfaces. If clay illuviation does not occur under steep landscape positions, the cambic horizon will be easily formed, also providing good conditions for placic horizon formation.

\subsection{Physical and chemical properties}

The soil physical and chemical properties of the selected pedons are listed in Table 3. Because slate is the parent material, the soils have fine soil texture compared with coarse-textured Podzolic soils formed in temperate regions (Clayden et al., 1990). The albic horizon (E) above the placic horizons have a coarser soil texture (such as silt loam or clay loam), but the cambic horizon (Bw) immediately underlying the placic horizons has finer soil textures (silty clay loam; Table 3). The clay content changes abruptly between the $\mathrm{E}$ and $\mathrm{Bw}$ horizons. Clay skins were not found in cambic horizon as determined by thin section analysis. This implies that clay illuviation does not occur, and the high clay contents of B horizons are from in situ weathering of the parent material. The changes of soil texture between AE2 and E horizon of $\mathrm{SH} 2$ pedon maybe result from the illuviation of clay moving from AE2 horizon downward to $\mathrm{E}$ horizon after formation of the placic horizon.

The placic horizon has a higher bulk density (1.30 to $1.98 \mathrm{Mg} / \mathrm{m}^{3}$ ) compared to other soil horizons of the pedon. This suggests that placic horizons are relatively impermeable in the subalpine forest region although there is a very high precipitation in the study area. 

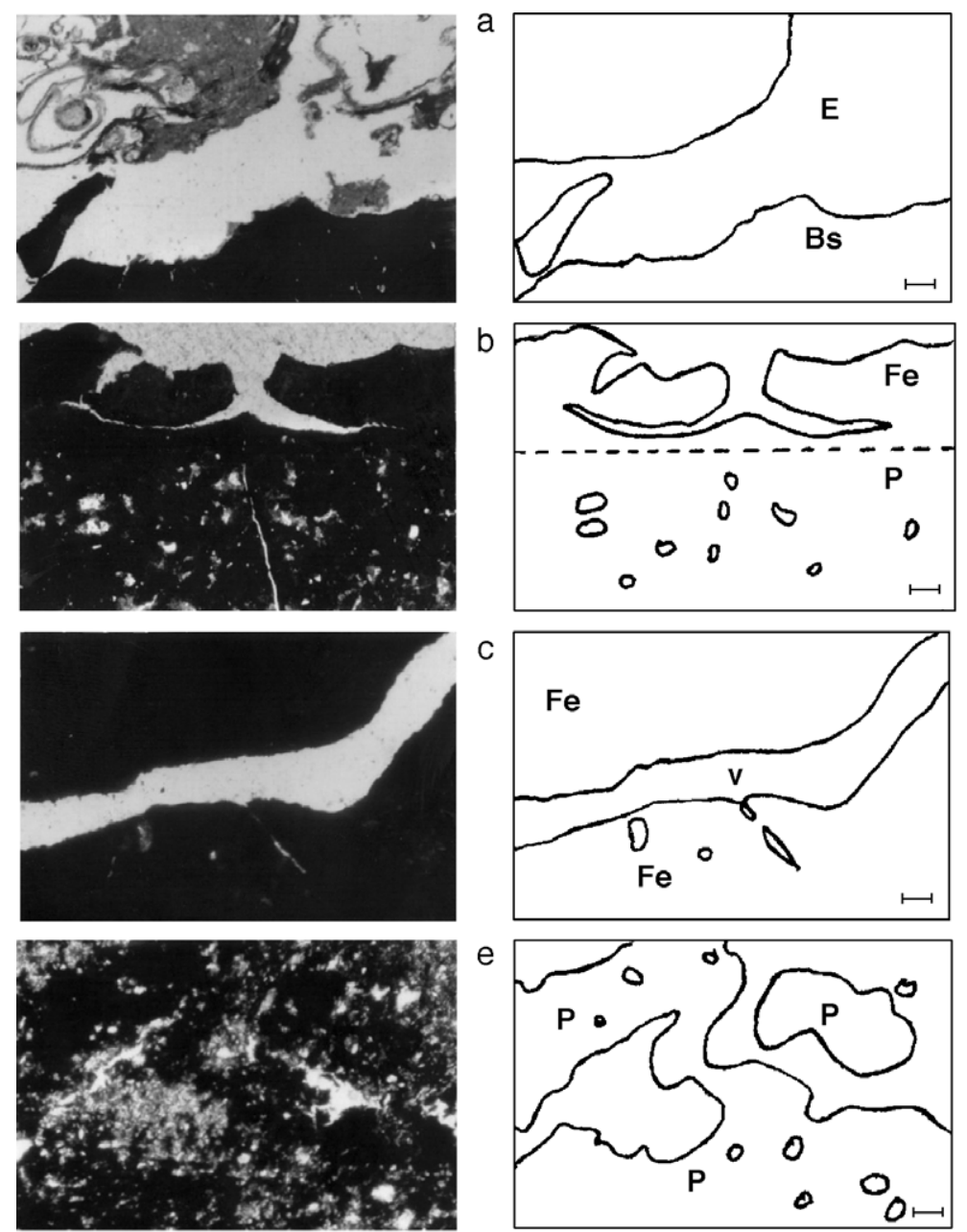

Fig. 3. (a) The picture showed the boundary area between E and Bs horizons of pedon SH1. The lower part of E horizon includes crystalline materials, and the upper part of Bs showed cracked and isotropic Fe matrices. Scale of bar is $0.5 \mathrm{~mm}$ (plane-polarized light). (b) The picture showed the micromorphological characteristics of the Bs horizon in pedon SH2. The upper part of placic horizon showed a red isotropic inorganic Fe oxide material (Fe), and the lower part of the Placic horizon showed dense plasma (P) with skeleton grains. Scale of bar is $0.5 \mathrm{~mm}$ (plane-polarized light). (c) The picture showed the micromorphological characteristics of the upper part of Bs horizon in pedon SH1. Voids (V) existed between cracked Fe matrices. Scale of bar is $0.01 \mathrm{~mm}$ (plane-polarized light). (d) The picture showed the micromorphological characteristics of the lower part of Bs horizon in pedon SH1. Dense plasma mixed with skeleton grains (P). Scale of bar is $0.01 \mathrm{~mm}(\mathrm{plane}-$ polarized light).

The $\mathrm{O} / \mathrm{A}$ and $\mathrm{E}$ horizons of the pedons have lower soil $\mathrm{pH}$ than the B horizons (Table 3). This provides a suitable environment for the formation of placic horizons (Clayden et al., 1990). The placic horizons have higher $\mathrm{pH}$ values than those above the E horizon (0.6-1.0 unit; Table 3), which is consistent with previous reports that placic horizons appears to be related to the precipitation of Fe or Mn that occurred under oxidizing conditions and higher soil $\mathrm{pH}$ (Lapen and Wang, 1999). Very low base saturation (except O/ A) was found in the three pedons and was presumed to be caused by strong leaching conditions associated with very high precipitation $(3000 \mathrm{~mm} /$ year $)$ in the study area. Organic C content of the placic horizon, only $2.3 \mathrm{~g} / \mathrm{kg}$, was almost equal to or slightly higher than that of upper $\mathrm{E}$ or lower $\mathrm{Bw}$ horizon of the pedons (Table 3). The distribution of cation exchange capacity (CEC) of the placic horizons was consistent 
Table 3

The physical and chemical properties of three pedons

\begin{tabular}{|c|c|c|c|c|c|c|c|c|c|c|c|}
\hline \multirow[t]{2}{*}{ Horizon } & \multirow[t]{2}{*}{ Depth $(\mathrm{cm})$} & \multicolumn{3}{|l|}{ Total } & \multirow[t]{2}{*}{ Soil texture } & \multirow[t]{2}{*}{ Bulk density $\left(\mathrm{Mg} / \mathrm{m}^{3}\right)$} & \multicolumn{2}{|l|}{$\mathrm{pH}$} & \multirow[t]{2}{*}{ Organic C (g/kg) } & \multirow[t]{2}{*}{$\mathrm{CEC}^{\mathrm{a}}(\mathrm{cmol}(+) / \mathrm{kg}$ soil $)$} & \multirow[t]{2}{*}{$\mathrm{BS}^{\mathrm{b}}(\%)$} \\
\hline & & Clay $(\mathrm{g} / \mathrm{kg})$ & Silt $(g / k g)$ & Sand $(g / k g)$ & & & $\mathrm{H}_{2} \mathrm{O}$ & $\mathrm{KCl}$ & & & \\
\hline \multicolumn{12}{|c|}{ SH1, elevation $2000 \mathrm{~m}$} \\
\hline $\mathrm{O} / \mathrm{A}$ & $0-3$ & 210 & 503 & 287 & $\mathrm{~L}$ & - & 5.9 & 4.5 & 7.0 & 13 & 78 \\
\hline E & $3-12$ & 205 & 603 & 192 & $\mathrm{SiL}$ & 1.21 & 4.7 & 2.9 & 1.8 & 4.2 & 15 \\
\hline Bs & $12-12.5$ & - & - & - & - & 1.66 & 5.6 & 4.1 & 2.3 & 13 & 3 \\
\hline Bw & $12.5-40$ & 296 & 552 & 152 & $\mathrm{SiCL}$ & 1.28 & 5.7 & 3.7 & 1.3 & 10 & 2 \\
\hline $\mathrm{C}$ & $>40$ & 185 & 255 & 560 & SL & - & 5.7 & 3.7 & 0.7 & 4.2 & 6 \\
\hline \multicolumn{12}{|c|}{ SH2, elevation $1920 \mathrm{~m}$} \\
\hline $\mathrm{O} / \mathrm{A}$ & $3-0$ & 257 & 453 & 318 & $\mathrm{~L}$ & - & 3.8 & 2.6 & 19 & 45 & 35 \\
\hline AE1 & $0-18$ & 218 & 682 & 100 & $\mathrm{SiL}$ & 1.19 & 4.1 & 2.9 & 3.2 & 8.9 & 4 \\
\hline AE2 & $18-27$ & 215 & 688 & 98 & $\mathrm{SiL}$ & 1.22 & 4.4 & 3.1 & 4.3 & 8.7 & 2 \\
\hline E & $27-36$ & 390 & 478 & 132 & $\mathrm{SiCL}$ & 1.27 & 5.0 & 3.4 & 2.4 & 15 & 2 \\
\hline Bs & $36-36.5$ & - & - & - & - & 1.98 & 5.4 & 4.2 & 2.3 & 20 & 3 \\
\hline $\mathrm{Bw}$ & $36.5-56$ & 385 & 508 & 107 & $\mathrm{SiCL}$ & 1.26 & 5.2 & 3.6 & 1.2 & 9.1 & 3 \\
\hline $\mathrm{C}$ & $>56$ & 190 & 230 & 580 & SL & - & 5.9 & 3.9 & 0.3 & 3.8 & 8 \\
\hline \multicolumn{12}{|c|}{ SH3, elevation $1940 \mathrm{~m}$} \\
\hline $\mathrm{O}$ & 5-0 & - & - & - & - & - & 4.4 & 4.1 & 270 & - & - \\
\hline A & $0-10$ & 242 & 473 & 285 & $\mathrm{~L}$ & - & 4.0 & 3.5 & 22 & 60 & 9 \\
\hline E1 & $10-15$ & 236 & 432 & 332 & $\mathrm{~L}$ & 1.20 & 4.0 & 3.5 & 9.8 & 14 & 1 \\
\hline E2 & $15-25$ & 314 & 481 & 205 & $\mathrm{CL}$ & 1.25 & 4.1 & 3.5 & 2.0 & 16 & 1 \\
\hline Bs & $25-25.3$ & - & - & - & - & 1.30 & 4.7 & 4.5 & 2.2 & 28 & 1 \\
\hline Bw1 & $25.3-55$ & 379 & 444 & 177 & $\mathrm{SiCL}$ & 1.18 & 4.9 & 4.3 & 1.4 & 19 & 1 \\
\hline Bw2 & $55-75$ & 390 & 414 & 196 & $\mathrm{SiCL}$ & 1.20 & 5.1 & 4.4 & 0.7 & 17 & 1 \\
\hline $\mathrm{BC}$ & 75-100 & 370 & 439 & 191 & $\mathrm{SiCL}$ & 1.26 & 5.1 & 4.4 & 0.9 & 14 & 1 \\
\hline $\mathrm{C}$ & $>100$ & 180 & 250 & 570 & SL & - & 5.8 & 4.0 & 0.2 & 6 & 5 \\
\hline
\end{tabular}

CEC - cation-exchange capacity.

b BS-base saturation percentage 
Table 4

The contents of $\mathrm{Fe}$ and $\mathrm{Al}$ of three pedons

\begin{tabular}{|c|c|c|c|c|c|c|c|c|c|c|c|c|c|}
\hline \multirow[t]{2}{*}{ Horizon } & \multirow[t]{2}{*}{ Depth (cm) } & \multicolumn{3}{|l|}{ Dithionite } & \multicolumn{2}{|l|}{ Oxalate } & \multicolumn{2}{|c|}{ Pyrophosphat } & \multirow[t]{2}{*}{$\mathrm{Al}_{\mathrm{o}}+1 / 2 \mathrm{Fe}_{\mathrm{o}}(\%)$} & \multirow[t]{2}{*}{$\mathrm{Fe}_{\mathrm{o}} / \mathrm{Fe}_{\mathrm{d}}$} & \multirow[t]{2}{*}{$\mathrm{Fe}_{\mathrm{p}} / \mathrm{Fe}_{\mathrm{o}}$} & \multirow[t]{2}{*}{$\mathrm{Al}_{\mathrm{p}} / \mathrm{Al}_{\mathrm{o}}$} & \multirow[t]{2}{*}{$\mathrm{ODOE}^{\mathrm{a}}$} \\
\hline & & $\mathrm{Fe}_{\mathrm{d}}(\mathrm{g} / \mathrm{kg})$ & $\mathrm{Al}_{\mathrm{d}}(\mathrm{g} / \mathrm{kg})$ & $\mathrm{Mn}_{\mathrm{d}}(\mathrm{g} / \mathrm{kg})$ & $\mathrm{Fe}_{\mathrm{o}}(\mathrm{g} / \mathrm{kg})$ & $\mathrm{Al}_{\mathrm{o}}(\mathrm{g} / \mathrm{kg})$ & $\mathrm{Fe}_{\mathrm{p}}(\mathrm{g} / \mathrm{kg})$ & $\mathrm{Al}_{\mathrm{p}}(\mathrm{g} / \mathrm{kg})$ & & & & & \\
\hline \multicolumn{14}{|c|}{ SH1, elevation $2000 \mathrm{~m}$} \\
\hline $\mathrm{O} / \mathrm{A}$ & $0-3$ & 26 & 2.6 & 1.1 & 7.2 & 2.9 & 3.7 & 2.5 & 0.65 & 0.28 & 0.51 & 0.86 & 0.32 \\
\hline E & $3-12$ & 3.0 & 0.4 & n. $d^{b}$ & 0.9 & 1.3 & 0.2 & 0.8 & 0.18 & 0.30 & 0.22 & 0.62 & 0.11 \\
\hline Bs & $12-12.5$ & 185 & 8.5 & 0.2 & 115 & 7.6 & 44 & 6.2 & 6.51 & 0.62 & 0.38 & 0.82 & 1.35 \\
\hline $\mathrm{Bw}$ & $12.5-40$ & 30 & 6.6 & 0.2 & 16.9 & 7.5 & 7.1 & 7.1 & 1.60 & 0.56 & 0.42 & 0.95 & 0.34 \\
\hline $\mathrm{C}$ & $>40$ & 17 & 2.9 & n.d & 9.1 & 4.3 & 3.5 & 3.7 & 0.89 & 0.54 & 0.38 & 0.86 & 0.16 \\
\hline \multicolumn{14}{|c|}{ SH2, elevation $1920 \mathrm{~m}$} \\
\hline $\mathrm{O} / \mathrm{A}$ & 3-0 & 1.5 & 0.3 & 0.2 & 1.5 & 1.1 & 0.3 & 0.5 & 0.19 & 1.00 & 0.20 & 0.45 & 0.08 \\
\hline AE1 & $0-18$ & 3.0 & 0.4 & n.d & 1.4 & 1.4 & 0.6 & 1.0 & 0.21 & 0.47 & 0.43 & 0.71 & 0.36 \\
\hline AE2 & $18-27$ & 0.8 & 1.1 & n.d & 0.8 & 2.2 & 0.3 & 1.8 & 0.26 & 1.00 & 0.38 & 0.82 & 0.58 \\
\hline $\mathrm{E}$ & $27-36$ & 24 & 6.2 & n.d & 7.0 & 5.8 & 7.8 & 5.8 & 0.93 & 0.29 & 1.11 & 1.00 & 0.74 \\
\hline Bs & $36-36.5$ & 101 & 4.5 & n.d & 44 & 2.0 & 36 & 2.6 & 2.40 & 0.44 & 0.81 & 1.30 & 1.94 \\
\hline $\mathrm{Bw}$ & $36.5-56$ & 51 & 7.4 & n.d & 19.2 & 4.7 & 30 & 5.9 & 1.43 & 0.38 & 1.56 & 1.26 & 0.56 \\
\hline $\mathrm{C}$ & $>56$ & - & - & - & - & - & - & - & - & - & - & - & - \\
\hline \multicolumn{14}{|c|}{ SH3, elevation $1940 \mathrm{~m}$} \\
\hline $\mathrm{O}$ & 5-0 & 1.7 & 1.0 & 0.8 & 2.0 & 1.4 & 1.0 & 1.5 & 0.24 & 1.18 & 0.50 & 1.07 & 0.08 \\
\hline A & $0-10$ & 6.0 & 1.8 & n.d & 8.5 & 3.3 & 5.8 & 3.4 & 0.76 & 1.42 & 0.68 & 1.03 & 0.96 \\
\hline E1 & $10-15$ & 0.3 & 1.1 & n.d & 0.4 & 2.0 & 0.3 & 2.0 & 0.22 & 1.33 & 0.75 & 1.00 & 0.17 \\
\hline E2 & $15-25$ & 0.4 & 1.2 & n.d & 0.3 & 1.9 & 0.2 & 2.0 & 0.21 & 0.75 & 0.67 & 1.05 & 0.19 \\
\hline Bs & $25-25.3$ & 159 & 5.5 & 0.1 & 109 & 4.7 & 37 & 4.8 & 5.92 & 0.69 & 0.34 & 1.02 & 1.48 \\
\hline Bw1 & $25.3-55$ & 27 & 3.9 & 0.1 & 28 & 8.5 & 33 & 8.7 & 2.25 & 1.04 & 1.18 & 1.02 & 0.80 \\
\hline Bw2 & $55-75$ & 23 & 3.8 & 0.2 & 20 & 7.3 & 26 & 15 & 1.73 & 0.87 & 1.30 & 2.05 & 0.58 \\
\hline $\mathrm{BC}$ & 75-100 & 21 & 4.6 & 0.3 & 16 & 6.2 & 21 & 8.4 & 1.42 & 0.76 & 1.31 & 1.35 & 0.35 \\
\hline $\mathrm{C}$ & $>100$ & - & - & - & - & - & - & - & - & - & - & - & - \\
\hline
\end{tabular}

ODOE - optical density of oxalate extraction

b n.d.-not detectable. 
with the distribution of soil organic C. The C distribution of pedons implies that there is no significant podzolization processes occurring in this study area (Hseu et al., 1999).

The distribution of different forms of $\mathrm{Fe}$ and $\mathrm{Al}$ in the three pedons is shown in Table 4. The maximum accumulation of iron $\left(\mathrm{Fe}_{\mathrm{d}}, \mathrm{Fe}_{\mathrm{o}}\right.$ and $\left.\mathrm{Fe}_{\mathrm{p}}\right)$ was found in the placic horizon (Table 4). The placic horizons appear to be dominated by free iron oxides $\left(\mathrm{Fe}_{\mathrm{d}}\right)$ and range from 101 to $185 \mathrm{~g} / \mathrm{kg}$. The depth distribution of $\mathrm{Fe}_{\mathrm{d}}$ indicated that large amount of $\mathrm{Fe}$ were eluviated from the E horizon and accumulated in the placic horizon. Extractable Al ranged from 5 to $15 \mathrm{~g} / \mathrm{kg}$ and was found in the $\mathrm{B}$ horizons ( $\mathrm{Bs}$ and $\mathrm{Bw}$ ) of the three pedons and was less than other forms of $\mathrm{Fe}$ in the $\mathrm{Bs}$ or Bw horizons (Table 4). The depth distribution of Fe and $\mathrm{Al}$ implies that there is no evidence on the formation of organo-iron or organo-aluminum complexes materials. This suggests that Spodosols are not present in the study area.

The ratio of $\mathrm{Fe}_{\mathrm{o}} / \mathrm{Fe}_{\mathrm{d}}$ in the placic horizons was 0.62 in pedon SH1, 0.44 in pedon $\mathrm{SH} 2$ and 0.69 in pedon SH3 (Table 4). This value is very similar to the ratio of other Inceptisols with placic a horizon, ranging from 0.7 to 0.8 (McKeague et al., 1967; De Coninck, 1980; Righi et al., 1982). This wide range of $\mathrm{Fe}_{\mathrm{o}} / \mathrm{Fe}_{\mathrm{d}}$ ratio suggests that some placic horizons are likely dominated by poorly crystalline goethite, lepidocrocite and ferrihydrite whose occurrence is enhanced by high amount of organic matter, as well as by wet moisture regimes (Champbell and Schwertmann, 1984; Chiang et al., 1994). Clayden et al. (1990) and Hseu et al. (1999) evaluated the formation of placic horizons and concluded that the reducing conditions required to mobilize the ferrous ion in the upper part of the profile resulted from high rainfall, cool temperature and low evapotranspiration of perudic regions. The reducing conditions were caused by seasonal saturation resulting from the formation of a slowly permeable subsurface horizon.

\subsection{Pedogenesis of placic horizon}

Several hypotheses have been proposed to explain the genesis of placic horizons (Crompton, 1952; Clayden et al., 1990; Conry et al., 1996; Hseu et al., 1999; Lapen and Wang, 1999). Clayden et al. (1990) concluded that placic horizon formed from $\mathrm{Fe}$, which was reduced and mobilized from the upper part of the pedon and then reoxidized and precipitated in the Bs horizon. Lapen and Wang (1999) proposed that the formation of placic horizon appears to be linked to the precipitation of mobile ferrous ion at higher $\mathrm{pH}$ and oxidizing soil conditions below the mineral soil surface. Besides, the perched water could provide the reducing conditions in the placic horizon to reduce $\mathrm{Fe}$ (Crompton, 1952). The genesis of placic horizons is quite different from the podzolization process. Spodic horizons are base on the accumulation of organic $\mathrm{C}, \mathrm{Al}$, with or without $\mathrm{Fe}$ (Soil Survey Staff, 1999). Conry et al. (1996) and Hseu et al. (1999) also concluded that podzolization and placic horizon development were fundamentally different processes.

Significant accumulation of $\mathrm{Fe}$ and $\mathrm{Mn}$ in the placic horizons indicate that inorganic ferrous $\mathrm{Fe}$ can be leaching from $\mathrm{E}$ horizon and accumulating in the $\mathrm{B}$ horizons. Because Fe was the dominant cation of the pedon, this may explain why the placic horizons were present in the study area. Conversely, spodic materials or organic-metallic complexes were not formed in the study area because of the absence of $\mathrm{Al}$ and organic $\mathrm{C}$ in the pedons.

The perched water appears to provide the essential preliminary condition for the development of placic horizons. The major reason for perched water formation is the abrupt texture changes of the pedons. The particle-size distribution of three pedons indicated that the clay content of horizon below the placic horizon was higher than that of the albic horizon (Tables 2 and 3). The micromorphological features also indicated that there is no significant clay illuviation in the cambic (Bw) horizons. We speculate that the perched water table should remain on the albic (E) horizon for several weeks to reduce Fe. The evidence of this reduction is the white color and massive structure in albic (E) horizon. When the soil condition changed to oxidizing with respect to $\mathrm{Fe}$ after the perched water drained, the reduced $\mathrm{Fe}$ will be reoxidized and accumulate at the boundary of the $\mathrm{E}$ and $\mathrm{Bw}$ horizon to form the placic horizon. Therefore, we find the boundary of placic horizons always have a wavy or irregular boundary, and the placic horizon occurs as a very thin layer $(2-5 \mathrm{~mm})$ above the $\mathrm{Bw}$ horizon. 


\subsection{Soil classification}

The soil color of the placic horizon are red (2.5YR $5 / 8)$ or dark red $(2.5 \mathrm{YR} 4 / 6)$. Although the soil chemical analysis of $\mathrm{Al}_{\mathrm{o}}+1 / 2 \mathrm{Fe}_{\mathrm{o}}$ and ODOE of placic horizon is more than two times of those in the Albic E horizon (Table 4), the depth of the placic horizon was too thin to identify as a spodic horizon. The horizon below the placic horizon can be identified as a cambic horizon. The soil moisture regime in the study area is perudic. Thus, the selected three pedons can be classified as Lithic Dystrudept or Oxyaquic Dystrudept based on Soil Taxonomy (Soil Survey Staff, 1999) or Dystric Cambisol based on World reference base for soil resources system (WRB system; ISSS Working Group WRB, 1998). For these three pedons, we cannot find a suitable Soil Great Group, or a Subgroup for Inceptisols that have the characteristics of placic horizons. Therefore, we propose that a Placic Dystrudept should be included in the Subgroup of Dystrudepts in the Soil Taxonomy (Soil Survey Staff, 1999) or a Placic Cambisol should be included in the Subgroup of Cambisols in the WRB system.

\section{Conclusion}

The development of podzolization and placic horizons are fundamentally different processes. From the soil macro- and micromorphological, physical, and chemical characteristics, we hypothesize the genesis of placic horizon in the study area occurs as two stages. In the first stage, E horizon is saturated with perched water due to the textural changes between albic (E) horizon and cambic $(\mathrm{Bw})$ horizon. This may have in turn produced the irregular surface of the albic horizon as well as the abrupt and wavy lower boundary of the placic horizon. In the second stage, soluble Fe is reduced and mobilized from upper part of the pedon into the Bw horizon and re-oxidized and precipitated at the boundary of the $\mathrm{E}$ and $\mathrm{Bw}$ horizons after the perched water has drained. In this condition, the placic horizons have a wave or irregular boundary and are expressed in a very thin layer (2-5 $\mathrm{mm})$. Placic horizon genesis may also relate to the precipitation of mobile $\mathrm{Fe}$ at higher soil $\mathrm{pH}$ value
(0.6 1.0 unit) and oxidizing soil contacts below the mineral soil surface. The placic horizons appear to be dominated by amorphous iron and free iron oxides.

There is no evidence of the illuviation of clay particles in the B horizon formed in the study area. The selected three pedons can be classified as Lithic Dystrudept or Oxyaquic Dystrudept based on USDA Soil Taxonomy or can be classified as Cambisols based on World reference base system. We propose that a Placic Dystrudept should be included in the subgroup of Dystrudepts in the Soil Taxonomy.

\section{Acknowledgement}

The authors would like to thank the National Science Council of the Republic of China for partially financial supporting this research under Contract No. NSC 91-2621-B-002-003.

\section{References}

Blake, G.R., Hartge, K.H., 1986. Bulk density. In: Klute, A. (Ed.), Methods of soil analysis: Part 1. Physical and mineralogical methods. 2nd ed. Agron. Monogr. 9. ASA and SSSA, Madison, WI, USA, pp. 363-376.

Bullock, P., Fedoroff, N., Jongerius, A., Stoops, G., Tursina, T., 1985. Handbook for Soil Thin Section Description. Waine Research Publications, Wolverhampton, UK, pp. 152.

Brewer, R., 1964. Fabric and Mineral Analysis of Soils. J. Wiley and Sons, New York.

Champbell, A.S., Schwertmann, U., 1984. Iron oxide mineralogy of placic horizons. J. Soil Sci. 35, 569-582.

Chen, Z.S., Tsai, C.C., 2000. Morphological characteristics and classification of Podzolic soils in Taiwan. Soil Environ. 3, 49-62. (In Chinese, with English abstract tables and figures).

Chen, Z.S., Lin, K.C., Chang, J.M., 1989. Soil characteristics, pedogenesis, and classification of Beichateinshan Podzolic soils, Taiwan. J. Chin. Agric. Chem. Soc. 27, 145-155.

Chen, Z.S., Liu, J.C., Chiang, H.C., 1995. Soil properties, clay mineralogy, and genesis of some alpine forest soil in Ho-Huan Mountain area of Taiwan. J. Chin. Agric. Chem. Soc. 33, 1-17.

Chiang, H.C., Cheng, Y.W., Yang, J.H., Horng, F.W., Wang, M.K., 1994. Iron oxides in placic horizon of alpine forest soils. J. Chin. Agric. Chem. Soc. 32, 666-674.

Clayden, B., Daly, B.K., Lee, R., Mew, G., 1990. The nature, occurrence, and genesis of placic horizons. In: Kimble, J.M. (Ed.), Proceedings of Fifth International Soil Correlation Meeting, USDA-SCS, Lincoln, pp. 88-104.

Conry, M.J., DeConinck, F., Stoops, G., 1996. The properties, genesis and significance of a man-made iron pan Podzol near Castletownbere, Ireland. Eur. J. Soil Sci. 47, 279-284. 
Crompton, E., 1952. Some morphological features associated with poor soil drainage. J. Soil Sci. 3, 277-289.

Daly, B.K., 1982. Identification of Podzols and podzolized soils in New Zealand by relative absorbance of oxalate extracts of A and B horizons. Geoderma 28, 29-38.

De Coninck, F., 1980. Major mechanisms in formation of spodic horizons. Geoderma 24, 101-128.

Gee, G.W., Bauder, J.W., 1986. Particle-size analysis. In: Klute, A. (Ed.), Methods of soil analysis: Part 1. 2nd ed. Agron. Monogr. 9. ASA and SSSA, Madison, WI, USA, pp. 383-411.

Hseu, Z.Y., Chen, Z.S., Wu, Z.D., 1999. Characterization of placic horizons in two subalpine forest Inceptisols. Soil Sci. Soc. Am. J. 63, 941-947.

ISSS Working Group WRB., 1998. World Reference Bases for Soil Resources: Introduction. In: Deckers, J.A., Nachtergaele, F.O., and Spaargaren, O.C. (Eds.), First edition. International Society of Soil Science (ISSS), International Soil Reference and Information Centre (ISRIC), and Food and Agriculture Organization of the United Nations (FAO). Acco. Leuven. pp. 165.

Lapen, D.R., Wang, C., 1999. Placic and Ortstein horizon genesis and peatland development, southeastern Newfoundland. Soil Sci. Soc. Am. J. 63, 1472-1482.

Li, S.Y., Chen, Z.S., Liu, J.C., 1998. Subalpine loamy Spodosols in Taiwan: characteristics, micromorphology, and genesis. Soil Sci. Soc. Am. J. 62, 710-716.

Liu, J.C., Yang, C.H., Chiang, H.C., Guo, H.Y., Chen, Z.S., 1994. Soil properties, clay minerals and genesis of montane soils in Chilan region, northern Taiwan. J. Chin. Agric. Chem. Soc. 32, $612-626$

Loveland, P.J., Digby, P., 1984. The extraction of Fe and Al by 0.1 M pyrophosphate solutions: a comparison of some techniques. J. Soil Sci. 35, 243-250.

McKeague, J.A., Day, J.H., 1966. Dithionite and oxalate extractable $\mathrm{Fe}$ and $\mathrm{Al}$ as aids in differentiating various classes of soils. Can. J. Soil Sci. 46, 13-22.
McKeague, J.A., Schnitzer, M., Heringa, P.K., 1967. Properties of an ironpan humic Podzol from Newfoundland. Can. J. Soil Sci. $47,23-32$.

McKeague, J.A., Damman, A.W.H., Heringa, P.K., 1968. Ironmanganese and other pans in some soils of Newfoundland. Can. J. Soil Sci. 48, 243-253.

McKeague, J.A., DeConinck, F., Franzmerier, D.P., 1983. Spodosols. In: Wilding, L.P., et al. (Eds.), Pedogenesis and soil taxonomy: Part 2. The soil orders. Elsevier, New York, pp. 245.

McLean, E.O., 1982. Soil pH and lime requirement. In: Page, A.L. et al. (Eds.), Methods of Soil Analysis: Part 2. Chemical and Microbiological Methods. 2nd ed. Agron. Monogr. 9. ASA and SSSA, Madison, WI, USA, pp. 199-224.

Mehra, O.P., Jackson, M.L., 1960. Iron oxides removed from soils and clays by a dithionite-citrate system buffered with sodium bicarbonate. Clays Clay Miner. 7, 317-327.

Nelson, D.W., Sommers, L.E., 1982. Total carbon, organic carbon, and organic matter. In: Page, A.L. et al. (Eds.), Methods of Soil Analysis: Part 2. Chemical and Microbiological Methods. 2nd ed. Agron. Monogr. 9. ASA and SSSA, Madison, WI, USA, pp. 539-579.

Righi, D., Van Ranst, E., De Coninck, F., Guillet, B., 1982. Microprobe study of a Placohumod in the Antwerp Campine (North Belgium). Pedologie 32, 117-134.

Soil Survey Staff, 1975. Soil Taxonomy: U.S. Govt. Agric., Handbook, vol.436. U.S. Govt. Printing Office, Washington, DC.

Soil Survey Staff, 1999. Soil taxonomy: a basic system of soil classification for making and interpreting soil surveys, 2nd ed. USDA-NRCS, Agricultural Handbook, vol. 436. U.S. Gov. Print. Office, Washington, DC.

Thomas, G.W., 1982. Exchangeable cation. In: Page, A.L. et al. (Eds.), Methods of Soil Analysis: Part 2. Chemical and Microbiological Methods. 2nd ed. Agron. Monogr. 9. ASA and SSSA, Madison, WI, USA, pp. 159-165. 